GÁBOR PAUER, Ph.D. Student ${ }^{1}$

(Corresponding author)

E-mail: pgabor90@gmail.com

ÁRPÁD TÖRÖK, Ph.D. ${ }^{1}$

E-mail: arpad.torok@auto.bme.hu

${ }^{1}$ Budapest University of Technology and Economics

Faculty of Transportation Engineering and Vehicle

Engineering, Department of Automotive Technologies

Múegyetem rkp. 3, 1111 Budapest, Hungary
Traffic Planning

Preliminary Communication

Submitted: 2 Jan. 2019

Accepted: 8 July 2019

\title{
COMPARING SYSTEM OPTIMUM-BASED AND USER DECISION-BASED TRAFFIC MODELS IN AN AUTONOMOUS TRANSPORT SYSTEM
}

\begin{abstract}
The paper introduces a framework to perform the demand management and route planning tasks of a highly developed transport system managing scheme, assuming an autonomous transport system. Two types of autonomous transport system managing models have been introduced. In case of the first model, the assigned number of trips is assumed to be the modified variable related to the optimization problem. In case of the second model, the decision process is directly influenced by the travel prices defined by the optimization method. These approaches represent different demand management strategies. The first model aims to directly assign the incoming user demands to the system, while the second procedure lets the users make the decision. However, in the second case the system can strongly influence the users' choices through the values of the travel prices. Accordingly, it seems to be a reasonable assumption that the firstly presented model has significantly higher efficiency in distributing the load on the network. On the other hand, the method of the second model would be much more tolerable and acceptable from a social point of view. Therefore, the aim of the paper is to introduce the developed models and to compare their efficiencies.
\end{abstract}

\section{KEY WORDS}

optimization; traffic distribution; road toll; linear programming; autonomous system;

\section{INTRODUCTION}

The aim of our research was to elaborate a decision-support process to perform the demand management and the route planning tasks of a transport system managing scheme. The transport system is assumed to be built up from a pre-defined infrastructure network, a vehicle fleet operated automatically by the transport system managing framework, and the demand as an external variable derived from the mobility objectives of the travellers. According to our assumptions, the travellers can only define the destination and the time of their travel demand and so the users have no possibility of controlling the mobility process. This assumption can only be achieved in an autonomously operating transport system.

Accordingly, the paper introduces two possible types of autonomous transport system managing models applying the tools of operation research [1], to solve the defined linear programming problems. The introduced approaches represent different demand management strategies.

In case of the first model, the assigned capacity is assumed to be the modified variable related to the optimization problem; therefore, the travellers are directly ordered to journeys by the system. The aim of the process is to minimize the total travel time with satisfying most travel demands.

In case of the second model, the decision process is assumed to be controlled by the travellers themselves. However, the willingness-to-pay characteristics of the road users is considered to be known, so that the decisions are influenced by the travel prices defined by the system in a time-variant way.

According to our first model, routing and transport processes of the system are completely controlled by the system autonomously, considering the possibilities of autonomous and semi-autonomous transport systems [2]. It is assumed that the travellers can select the origin and destination locations of a certain trip freely; however, the route of the given trip is defined by the transport demand management system [3]. Based on this approach it is possible to organize the traffic demand structure of a given area reasonably close to the optimum [4]. However, the capacity constraints of the network can cause difficulties in the optimization process. In case of an overloaded situation the system would need to rank behind and postpone some of the trips.

In case of a purely demand-led system, automatic ranking decisions would generate malcontent users. Therefore, this decision has been transmitted to the 
users in the second model, by applying a demand-dependent, marginal cost-based management process, which can be an adequate tool to affect the road users' decisions without taking over the right of decision from the travellers. In this case a price-dependent demand function can be applied to determine the effect of the change in the travel costs and to influence the traffic structure.

Based on the above introduced approaches it seems to be a reasonable assumption that the direct assignment method of the first model has significantly higher efficiency in distributing the load on the network. However, the method of the second model seems to be socially more tolerable and acceptable, not completely controlling all the decisions related to the travels. In accordance with these considerations, the aim of our research was to determine and evaluate the difference between the efficiencies of the analysed models.

Beyond the general description of the developed methodology, it is outstandingly important to specify the relationship between the problem addressed in this paper and the four-step modelling [5], since fourstep transportation model is still a reference-point for novel modelling approaches in the field of transportation. First of all, it seems to be reasonable to start the comparison with the main purpose of the models.

The four-step models primarily aim to estimate the traffic volumes to the components of the network. The four-step model uses the initial mobility demand structure represented by origin-destination matrices and the supply side of the model represented by the capacity network values to define the assigned traffic volumes. This framework allows the decision maker to analyse how much a network development intervention can improve the efficiency of the whole system.

Contrary to this, the main purpose of the developed model framework is to support dynamic capacity allocation processes in an autonomous system by decomposing the investigated time frame to discrete model steps and by solving the identified capacity allocation problem. Besides, the model can also provide traffic volumes related to the network elements and it can be applied to analyse the network development interventions. However, its main objective focuses rather on the solution of a traffic management problem.

If the methodological parts of the two procedures are compared, the most striking differences can be identified in the procedure of traffic assignment. It can be concluded that in case of the four-step model, traffic assignment is mostly performed by some kind of iterative equilibrium algorithm, while in case of our model the traffic volumes of the network elements are defined based on the solution of the applied inequality system.

\section{LITERATURE REVIEW}

There is extensive literature in the field of traffic optimization and network capacity utilization, based on various approaches.

Friesz et al. have presented in their paper a dualtime-scale formulation of dynamic user equilibrium (DUE) with demand evolution [6]. Their research has combined the within-day time scale for which route and departure time choices fluctuate in continuous time with the day-to-day time scale for which demand evolves in discrete time steps. The applied representation framework is consistent with the assumption that the drivers adapt their mobility demands at the end of the day based on their congestion experience with regard to the previous days. To define the actual dynamic user equilibrium, Friesz et al. have introduced a continuous time fixed-point algorithm and have proven its convergence.

In contrast with the basic routing approach, the research paper [7] introduced a method in a multi-layered satellite network by adopting a traffic distribution model, which is based upon the network capacity estimation and theoretical analysis of the congestion rate in each layer. The reliability of this method has been validated through computer simulations.

Zhang et al. have introduced a novel model aiming to suggest a new framework for the transportation network design problem especially considering the definition of equity [8]. The research has three main findings. Accordingly, a new metric has been developed focusing on describing the equity characteristics including the travel time and energy consumption of the network components. Besides, an efficient modelling framework has been developed meeting the requirements of the equity concept. And finally, the researchers have identified a tailored heuristic solution model, which represents the interrelation of decision makers and road users.

The traditional morning commute problem in urban environment considering the possibility of mode choice has been investigated in [9]. According to their representation, the commuters make their decisions related to the preferred mode aiming to minimize their total travel cost, while transit agencies decide when to operate. Besides, the authors of this paper have investigated the street space as a limited resource shared by cars and public transit, which is a reasonably forward-looking consideration. Li et al. have introduced a new toll-design model supporting the formation of sustainable transport networks. The new approach combines environmental externalities and travel time related considerations in the model [10].

Although these studies have provided valuable results, the assumption of arranging our travel demand properties according to our congestion experience during the day is not completely correct any more. The 
main reason for this is the spread of the traffic-dependent, real-time navigation systems, which change fundamentally the route choice-related processes of the road users. Accordingly, the new model development processes should focus on the representation of a connected and automated transportation system.

Besides, in case of the evaluated studies it has to be stated again that the decisions of the road users are getting more and more restricted to the selection of destination, while for example other process components, like the process of route planning is getting more and more automated. Therefore, it seems to be reasonable to represent the decisions related to the mobility process in accordance with the new tendencies.

\section{METHODOLOGY}

In order to evaluate the differences, linear programming approach [11] has been used to determine the static system optimum of a special interpretation of the traffic distribution problem [12], based on the elaborated transport system managing models. The aim of the generated optimization problem was to satisfy the pre-defined travel demands on three different transport networks determining the minimum of the total travel time value (which is the function of the total traffic appearing on the network), while satisfying most transport demands.

As it has been introduced, in the first model the transport demands have been directly distributed on the network. The second model represents a costbased management process where traffic flows have been estimated based on the road toll structure.

The considered traffic distribution problem is special since the investigated transport system and its elements have been assumed to be totally autonomous. This makes the road users' decision process simpler, since the traveller only needs to determine their destination instead of managing the whole transport process. The trip distribution optimization on the system level is controlled by the transport managing system, taking into account the necessary conditions to obtain the system optimum [13]. Considering the aim of the optimization process, the objective function includes the sum of products of traffic volumes of routes (partflows) and related travel times; taking also into account the unsatisfied transport demands (missed travels).

In our previous studies, the optimization processes of a specific traffic distribution problem have been introduced briefly in case of a pre-defined transport network, considering the characteristics of the network elements, transport demands and alternative routes between the origin-destination zones (OD zones) as pre-defined static parameters [12, 14, 15]. These methodologies have been further improved and trans- formed into general models allowing the investigation of different network types, in line with the purpose of this research.

In the elaborated models, the transport networks have been represented by graphs [16]. Nodes of the graphs represent the intersections of the network, while the edges of the graphs represent the infrastructure sections (roads) [17]. The number of OD zones has been considered as a finite value. Alternative routes between OD zones have been built up from graph edges $u_{j}$ representing the most relevant paths linking the investigated OD pairs. The capacity of edges $c_{j}$ represents the maximum possible number of travellers on a road in a sample time period. Travel time of edges $t_{j}$ represents the time needed to travel through the infrastructure section. As the aim of the method is to define the static system optimum, these parameters as well as the transport demands $D$ have been considered as constant values (pre-recorded data) in our model.

In the second model, road toll structure has been derived from the travel costs of the sections of the road network (travel cost of edge $u_{j}$ has been indicated by $k_{j}$ ). Accordingly, the cost of travelling on the $i$-th route ( $U_{i}$-between two $O D$ zones) has been equal to the sum of the costs of the edges contained by the route, and has been indicated by $K_{i}$. Part-flows have been estimated based on the willingness-to-pay functions, which have been approximated by linear functions in our research.

Summing up, the aim of the models has been to satisfy most travel demands between OD zones causing a minimum growth in travel time considering traffic flows that appeared on the transport network in a sample time period of the model [18]. The variables of the first model have been the traffic volumes of alternative routes (part-flows) of the network, while in the second model the costs of the edges have been the primary system variable (which have directly influenced the part-flows of the alternative routes). The constraints have been calculated from the capacity of the edges and the pre-defined travel demands between OD pairs. The minimized objective function has been derived based on the sum of products of part-flows and the related travel times, taking also into account the unsatisfied transport demands.

While constructing the models solving the considered traffic distribution problem, the possible alternative routes $U_{i}$ of the investigated transport network have to be determined as the first step. The traffic volume of the alternative routes has been represented by part-flow $x_{i}$ variables. The traffic volumes of the edges have been indicated by $X_{j}$.

As mentioned above, the transport network sections (graph edges) have been characterized by their capacities. Besides, in the second model, the partflows of the routes have been the function of the cost 
of the routes. According to the system concept of the second model, the system determines the road toll level (cost structure) in accordance with the ratio of the network capacity and the appeared transport demands. Based on the amount of demand and the capacity limit, the system can estimate the number of postponed trips, and thus transform real-time travels to latent demands. As a consequence, in some cases the transport demands cannot be satisfied (e.g. if capacities of the network are exhausted, or the travel cost is too high for the given road user).

To manage the problem, the postponed travels have been loaded on "fictive routes" during the optimization. Therefore, a fictive route has been introduced between each OD pair. Fictive routes have been indicated by $U_{i}^{\prime}$. In order to satisfy most transport demands and minimize the use of fictive routes, extremely high travel time values $t_{i}$ ' have been ordered to fictive routes. The capacities of these routes have not been constrained to be able to host all the postponed travels. Part-flows of fictive routes have been indicated by $x_{i}^{\prime}$. Based on the considerations above, the models have been complemented by part-flow variables of fictive routes which have been taken into account in case of the objective function.

The general models describing the optimization method of the traffic distribution problem are introduced as follows, considering a transport network with $q$ OD pairs, $m$ infrastructure sections and $n$ alternative routes.

Values of $x_{i}$ and $x_{i}^{\prime}$ are required to be a non-negative integer (as they represent traffic volumes of real and fictive routes), as defined in Equations 1 and 2.

$$
\begin{aligned}
& x_{i} \geq 0, \text { and } x_{i} \text { is integer; } i=1 \ldots n \\
& x_{i}^{\prime} \geq 0, \text { and } x_{i}^{\prime} \text { is integer; } i=1 \ldots q
\end{aligned}
$$

Furthermore, in case of the second model, the costs of the edges are required to be non-negative, as defined in Equation 3.

$$
k_{j} \geq 0 ; j=1 \ldots m
$$

Travel demands between OD zones have been considered as pre-defined constant data, so that the boundary conditions related to the traffic volume of the routes could also be constructed.

Travel demand $D$ between a given OD zone-pair has been equal to the sum of part-flows of the alternative real routes, and part-flow of the introduced fictive route between the given zones, as illustrated in Equation 4, where for instance the considered origin zone is indicated by $S$ and the destination zone is indicated by $W$.

$$
D_{S W}=\sum\left(x_{i}+x_{i}^{\prime}\right)
$$

The considered part-flows (values of index $i$ ) are determined based on the structure of the transport network: part-flows as the real alternative routes between $S$ and $W$ zones have to be summed up, the part-flow of the fictive route (missed travels) between $S$ and $W$ also has to be added.

To describe the correspondences between routes and edges, an $m \times n$ sized coefficient matrix $A$ has been introduced as follows:

$\underline{\underline{A}}=\left[\begin{array}{cccc}a_{11} & a_{12} & \ldots & a_{1 n} \\ a_{21} & \ddots & & \\ & & \ddots & \\ a_{m 1} & & & a_{m n}\end{array}\right]$

This matrix makes it possible to order the traffic volumes (and costs) of the edges to the traffic volumes (and costs) of the routes, and to express the objective function and the constraining conditions in terms of the optimized variables. The values of the matrix elements depend on the structure of the investigated transport network, so the matrix is not necessarily symmetric.

The number of the rows of the matrix is defined by the number of the edges of the graphs representing the transport network (road sections), while the columns are determined by the alternative routes between the origin-destination zones, and these values are not necessarily equal. The value of $a_{j i}$ is 1 , if the $j$-th edge is contained by the $i$-th route, and 0 , if it is not (in case of all $a_{j i}, j=1 \ldots m$ and $i=1 \ldots n$ ).

In the second model, the costs of the real routes depend on the optimized variables according to Equation 5, while part-flows of real routes depend on the cost of the routes according to the users' willingness to pay [19].

$K_{i}=\sum_{j=1}^{m}\left(k_{j} \cdot a_{j i}\right) ; i=1 \ldots n$

Part-flows of real routes can be expressed in terms of the optimized variables (cost of the edges) based on Equation 5 and the willingness-to-pay function defined by the example. The willingness-to-pay function describes the expected part-flow volumes of routes depending on the cost of the routes $x_{i}\left(K_{i}\right)$.

In the next step the constraining inequalities have been defined, based on the pre-defined capacities of the edges as follows by Equation 6.

$X_{j}=\sum_{i=1}^{n}\left(x_{i} \cdot a_{j i}\right) \leq c_{j} ; j=1 \ldots m$

Finally, the objective function has been defined. The aim is to minimize the total travel time of the vehicles travelling through the network in an investigated sample time period, also considering constant transport demands and capacity limits as constraining factors [20]. Therefore, the sum of products of traffic volumes and constant travel time values of the edges have been applied to construct the objective 
function, including also the sum of products of the fictive part-flows and their travel time values, as indicated by Equation 7.

$F=\sum_{j=1}^{m}\left(X_{j} \cdot t_{j}\right)+\sum_{i=1}^{q}\left(x_{i}^{\prime} \cdot t_{i}^{\prime}\right) \rightarrow \min$

Thus, part-flows of fictive routes (representing the postponed trips) have also been involved in variables based on the introduced considerations, and have been taken into account in the objective function. Models representing the optimization framework can be defined based on the introduced linear inequality system. Equations 1-7 describe the second model, while Equation 3 and Equation 5 are not required in the first model.

\section{SENSITIVITY ANALYSIS}

Based on the elaborated models, the static system optimum of the specific traffic distribution problem has been analysed in case of different transport network types, in light of the change (increase) in transport demands. As mentioned previously, our main goal was to compare the results of the two models.

Figure 1 introduces the structure of the three investigated transport networks.

Transport network I. represents a classic grid transport network with 2 origin ( $S$ and $T$ ) and 2 destination ( $W$ and $Z$ ) zones. Transport network II. represents a transport network with a significant separating effect (e.g. a river); therefore, two sub-parts of the network are connected by longer infrastructure sections. Transport network III. represents a centralized network structure where the peripheral nodes have fewer direct connections, and transport flows concentrate mostly in the middle of the network. In case of transport networks II. and III., 2 origin ( $S$ and $T$ ) and 3 destination ( $W, Y$ and $Z$ ) zones have been defined (see Figure 1 ).

In order to ensure comparability, the applied pre-defined parameter sets have been generated from the same basic values related to the elements of the different networks. Pre-defined data sets have been summarized in Table 1.

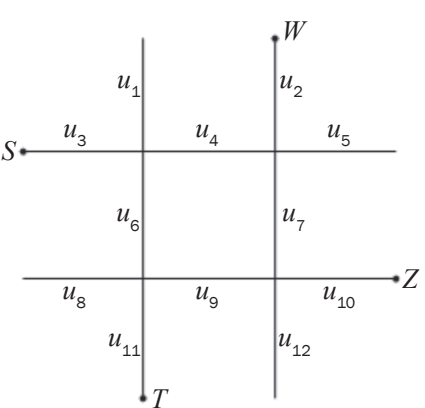

a) Transport network $I$.

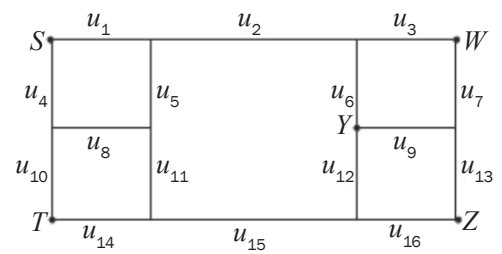

b) Transport network II.

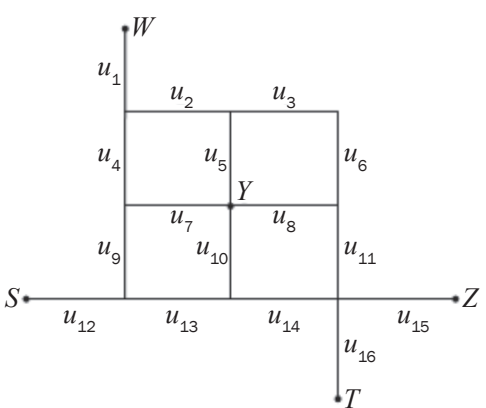

c) Transport network III.

Figure 1 - Structure of the investigated transport networks

Table 1 - Characteristics of the edges of the investigated transport networks

\begin{tabular}{|c|c|c|c|c|c|c|}
\hline & \multicolumn{2}{|c|}{ Transport network I. } & \multicolumn{2}{|c|}{ Transport network II. } & \multicolumn{2}{|c|}{ Transport network III. } \\
\hline Edges & Capacity $\left(c_{j}\right)$ & Travel time $\left(t_{j}\right)$ & Capacity $\left(c_{j}\right)$ & Travel time $\left(t_{j}\right)$ & Capacity $\left(c_{j}\right)$ & Travel time $\left(t_{j}\right)$ \\
\hline$u_{1}$ & 20 & 3 & 30 & $\overline{3}$ & 30 & 3 \\
\hline$u_{2}$ & 26 & 3 & 30 & 6 & 20 & 3 \\
\hline$u_{3}$ & 25 & 3 & 20 & 3 & 20 & 3 \\
\hline$u_{4}$ & 25 & 3 & 20 & 3 & 20 & 3 \\
\hline$u_{5}$ & 30 & 3 & 20 & 3 & 20 & 3 \\
\hline$u_{6}$ & 25 & 3 & 20 & 3 & 20 & 3 \\
\hline$u_{7}$ & 20 & 3 & 20 & 3 & 20 & 3 \\
\hline$u_{8}$ & 25 & 3 & 20 & 3 & 20 & 3 \\
\hline$u_{9}$ & 25 & 3 & 20 & 3 & 20 & 3 \\
\hline$u_{10}$ & 25 & 3 & 20 & 3 & 20 & 3 \\
\hline$u_{11}$ & 35 & 3 & 20 & 3 & 20 & 3 \\
\hline$u_{12}$ & 25 & 3 & 20 & 3 & 35 & 3 \\
\hline$u_{13}$ & - & - & 20 & 3 & 20 & 3 \\
\hline$u_{14}$ & - & - & 35 & 3 & 20 & 3 \\
\hline$u_{15}$ & - & - & 35 & 6 & 30 & 3 \\
\hline$u_{16}$ & - & - & 20 & 3 & 32 & 3 \\
\hline$u_{j}^{\prime}$ & $\infty$ & 300 & $\infty$ & 300 & $\infty$ & 300 \\
\hline
\end{tabular}


In case of the second model, it was assumed that road users would take into account the cost of the routes when making their travel decisions (travelling or not, choosing between the routes). Therefore, a linear function was required describing the part-flows of the routes as the function of the cost of the given route. In our analysis, the following linear function (Equation 8) has been used in case of all three investigated networks:

$x_{i}\left(K_{i}\right)=40-3 \cdot K_{i} ; i=1 \ldots n$

During the analysis, the sensitivity of the results has been investigated related to modified transport demands between the OD zones. In order to ensure comparability, similar starting points (transport demands) have been applied in case of all three networks, which have been summarized in Table 2 . The reason of the deviation is that Transport Network I. has had only two destination zones.

Table 2 - Transport demands on the investigated networks

\begin{tabular}{||c|c|c|c|}
\hline OD pairs & $\begin{array}{c}\text { Transport } \\
\text { network I. }\end{array}$ & $\begin{array}{c}\text { Transport } \\
\text { network II. }\end{array}$ & $\begin{array}{c}\text { Transport } \\
\text { network III. }\end{array}$ \\
\hline \hline$S-W$ & 12 & 8 & 8 \\
\hline$S-Y$ & - & 12 & 12 \\
\hline$S-Z$ & 8 & 10 & 10 \\
\hline$T-W$ & 12 & 8 & 8 \\
\hline$T-Y$ & - & 12 & 12 \\
\hline$T-Z$ & 8 & 10 & 10 \\
\hline
\end{tabular}

During the sensitivity analysis, the transport demands between the OD pairs have been increased evenly step by step. The optimization has been performed according to the presented methodologies of the models, with the use of MATLAB software. In the first model, the transport demands have been directly distributed on the network, considering part-flows of real and fictive routes as system variables. In the second model, part-flows of the alternative real routes have been determined as the function of the road toll structure. In this case, the cost of the edges and partflows of fictive routes have been considered as system variables. In both models, the aim of the decision process has been to minimize the total travel time of the vehicles travelling through the network in an investigated sample time period.

Based on the outcomes of the sensitivity analysis, the following parameters have been compared in case of different transport network types:

$p_{1}$ - total number of realized travels;

$p_{2}$ - total number of fictive travels (missed travels);

$p_{3}$ - total traffic on real edges (sum of the volume of traffic on real edges);

$p_{4}$ - the load on the real network (sum of products of traffic volumes and travel time values of the real edges).
Values of $p_{1}$ and $p_{2}$ describe the amount of realized transport demands, and the number of postponed travels in light of the defined capacity constraints characterizing the given transport network. Accordingly, the sum of $p_{1}$ and $p_{2}$ is always equal to the total transport demands. Parameter $p_{3}$ indicates the total traffic of the network. Parameter $p_{4}$ describes the load of the network. Values of the objective function have not been separately investigated during the sensitivity analysis as they have been calculated as the sum of parameter $p_{4}$ and the production of $p_{2}$ and the defined constant travel time values of fictive routes.

The results have been introduced in Figures 2-4 differentiated by network types and the adapted models (indicated in the subtitle of the figures as Model 1 and Model 2), to facilitate the comparison. The horizontal axes represent the volume of transport demands, using the previously introduced dataset as the starting point (see Table 2), increasing the demands between all OD pairs evenly step by step.

In case of the initial values, the transport demands of all the travellers can be realized in case of all transport networks. In this case, the total number of realized travels $\left(p_{1}\right)$ is equal to the defined transport demands, while the numbers of the postponed trips $\left(p_{2}\right)$ are 0 . The increments in demands increase the values of parameter $p_{1}$ to a certain amount until the network becomes saturated. From this point, the number of realized trips cannot be further increased. Accordingly, as the demands increase further, the number of the postponed trips begins to increase proportionally. At the same time, the total number of realized trips on the network is not modified with the increasing demands. However, the total traffic on real edges $\left(p_{3}\right)$ is still influenced by the amount of demand. The reason for this lies in different demand structures, which are caused by the permanent transformation of the structure of the realized and postponed trips, since the elaborated models (minimizing total network load) prioritize shorter trips compared to longer journeys. Therefore, in case of increased demands, a longer journey that has been previously realized can be postponed, and contrarily, a shorter trip between two closer OD pairs can be realized. This reduces the load of the network, while the number of postponed travels does not increase. However, beyond a certain amount of demand, the value of $p_{3}$ cannot change anymore. In this case the network is saturated by the shortest possible travels.

The "length" of travels is defined based on the travel time values of the network elements. The objective function is calculated as the sum of parameter $p_{4}$ and the product of $p_{2}$ and the defined constant travel time value of the fictive routes. In line with the increasing transport demands, the reason for the variation of $p_{3}$ values is that the optimization process aims to minimize $p_{4}$ values. So, the load of the real networks in all 


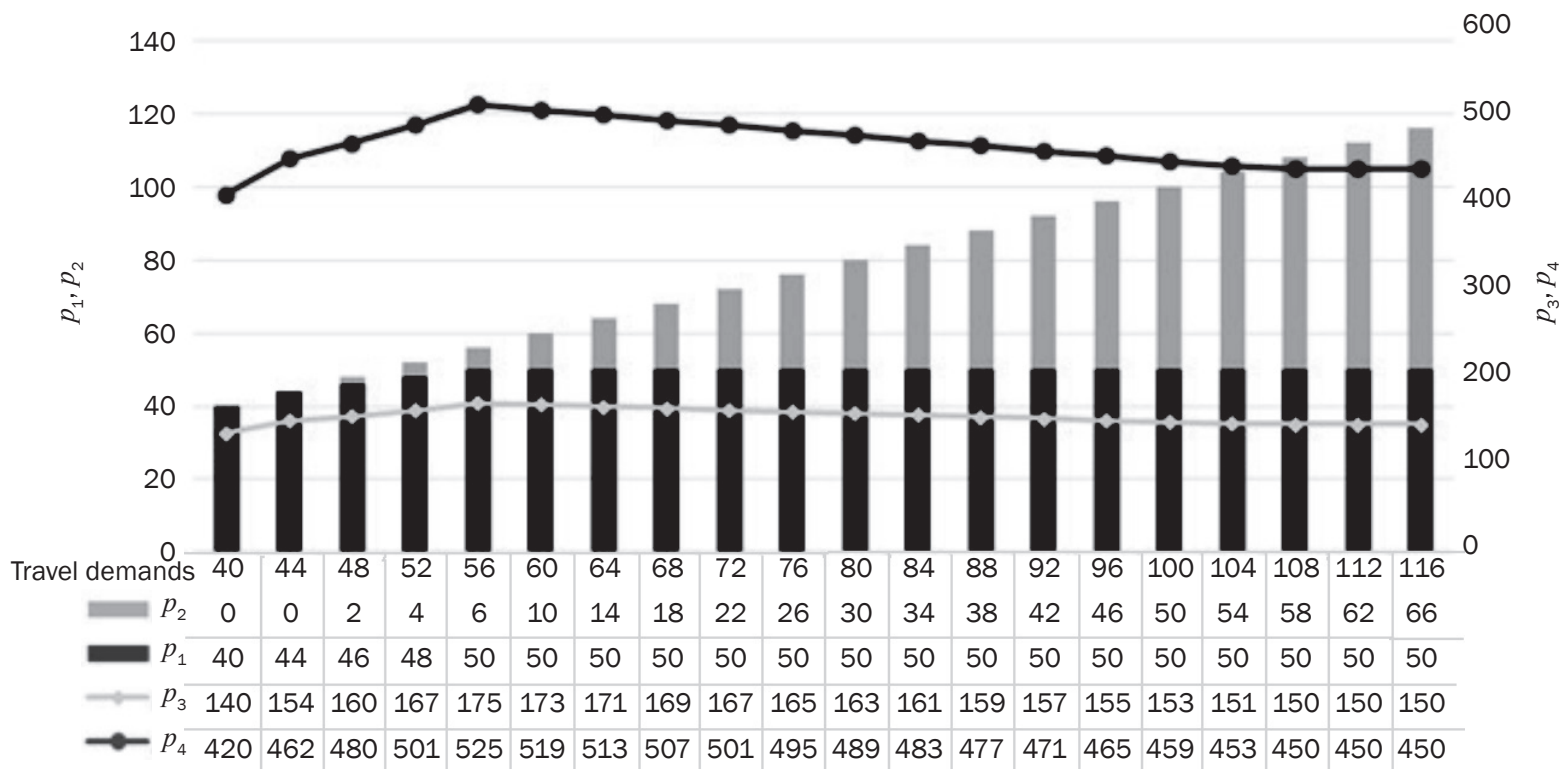

a) Results of Model I

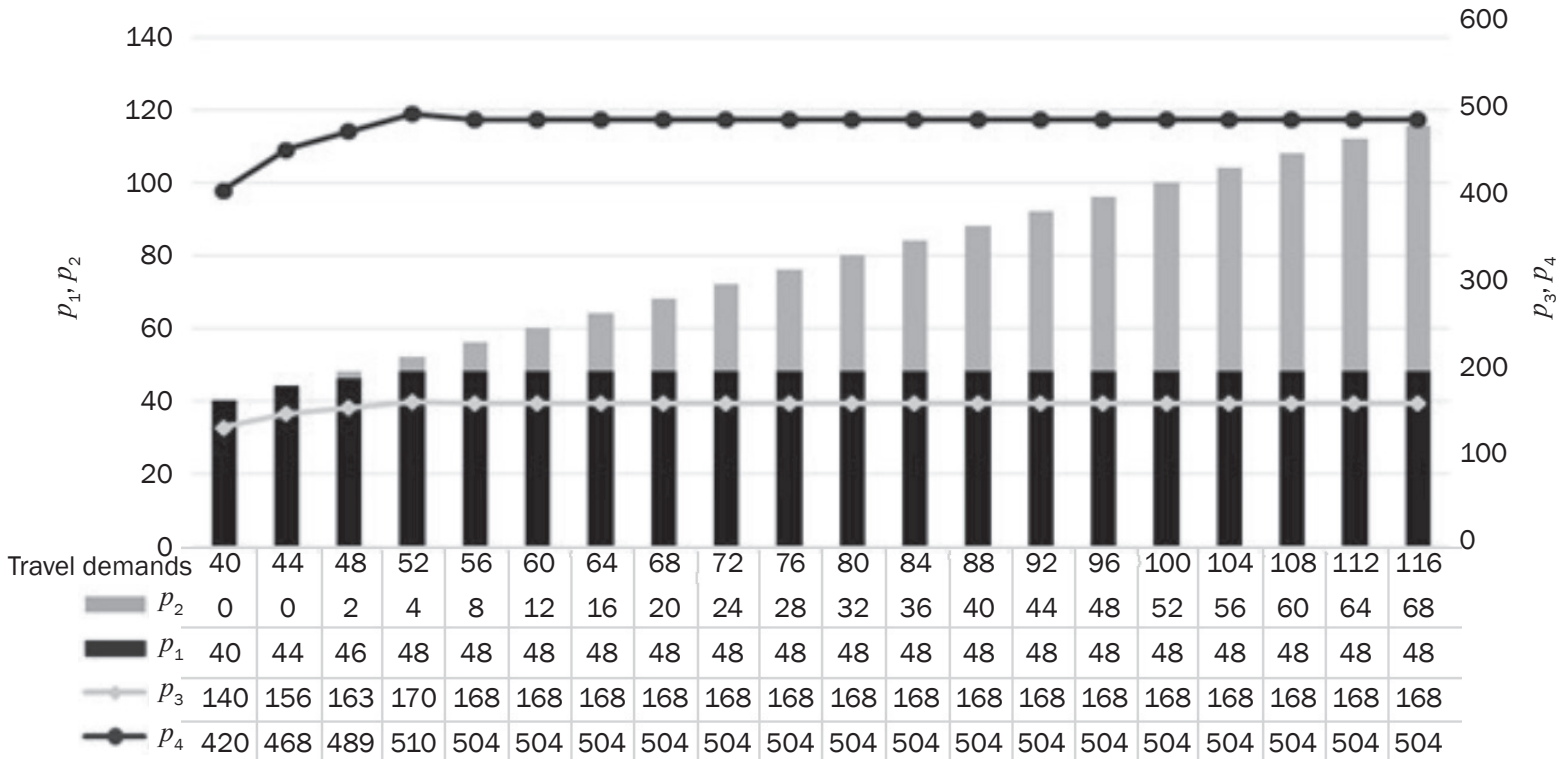

b) Results of Model II

Figure 2 - Parameter values in case of Transport network I

cases increases monotonically until the first saturation point. After that, it starts to decrease as the method prioritizes the new demands appearing on shorter (faster) routes compared to longer ones. In our examples, $p_{3}$ and $p_{4}$ values change in the same direction, since almost every edge has been characterized by the same travel time values; however, this is not generally true in every case. A case can be assumed in which a newly realized, emerging demand could be realized on a route containing more edges but being characterized by a shorter travel time compared to the route of a postponed, previously realized travel.

Results of the first and second model have been compared in case of all three transport networks. Based on the first model, the optimal traffic distribution has been determined as a reference, by directly distributing the travel demands. The second model applied a complex procedure adjusting the road toll structure to influence the travel demands towards approaching the reference optimum as close as possible.

The results proved that in case of these simplified examples, the cost-based model has managed to provide equivalent or only slightly less effective results related to parameters $p_{1}$ and $p_{2}$ compared to the first model. This result is an important milestone in the evolution process of the transport system managing framework schemes, since this outcome can prove the applicability of cost-based mobility process management models in the field of autonomous transport systems. In case of Transport network II, the method 


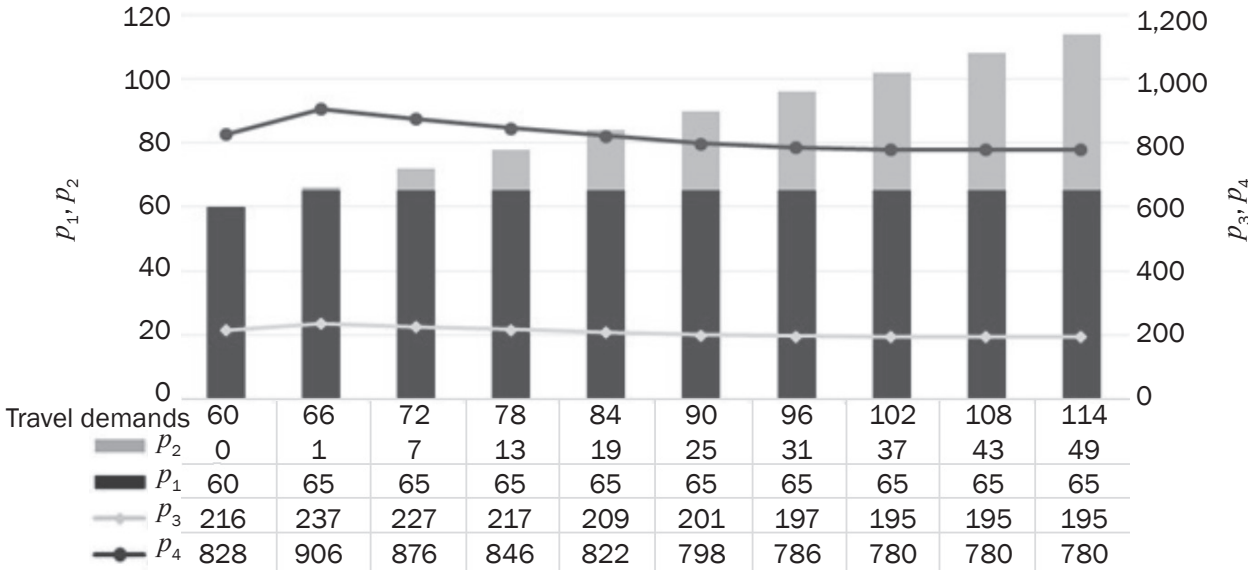

a) Results of Model I

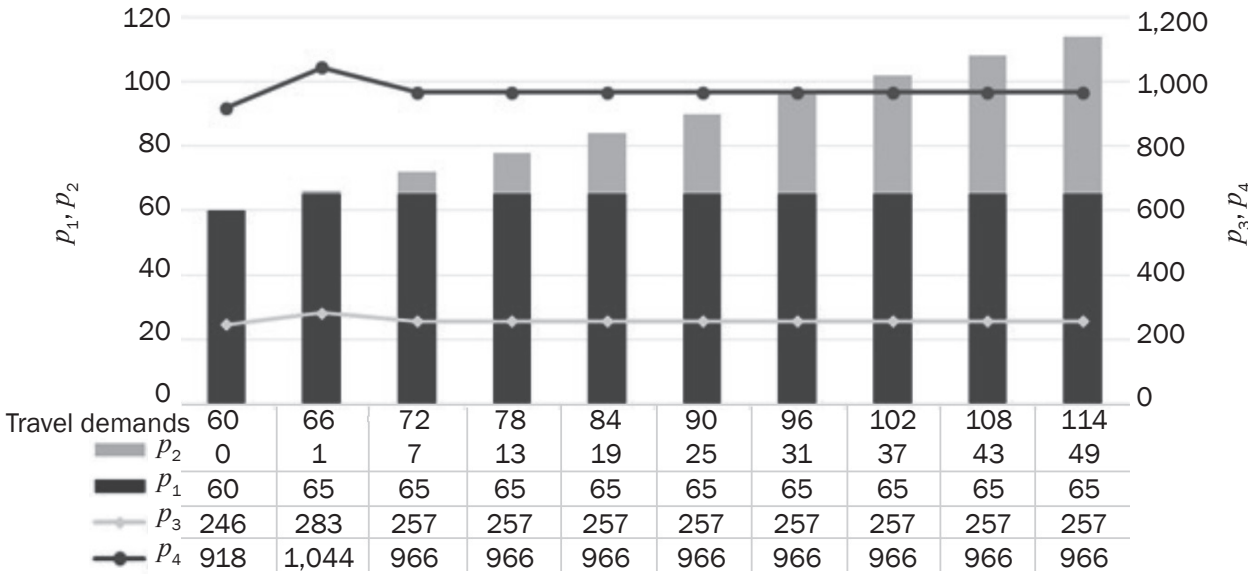

b) Results of Model II

Figure 3 - Parameter values in case of Transport network II

of the second model was able to determine a road toll structure in which the same volume of transport demands have been realized as in case of the first model. In case of Transport networks I and III, the differences have been experienced. In case of Transport network I, the saturation point was lower applying the second model (only 48 trips could be realized, compared to the 50 travels realized by the first model). Accordingly, the total number of postponed travels was higher. In case of Transport network III, there was only one demand structure (when the volume of demands was 66), where the method of the second model was less effective than the first one. Summing up, the second model was able to approach the reference optimum defined by the first model relatively well related to the number of realized travels.

As mentioned above, parameter $p_{3}$ indicates the distribution of the realized travels, while parameter $p_{4}$ illustrates the load of the network. Values of these parameters showed that in most cases, the transport demands have been satisfied somewhat less efficiently in light of the network load applying the second model. In most cases the road-toll-based optimization process resulted in higher load level on the network. On the other hand, the networks have been saturated "faster" (by lower transport demands) in case of the second model.

The reason for the differences is that the costs have been ordered to the edges (infrastructure sections) of the network, contrary to the alternative routes. This approach is closer to real-world transport systems, where charges are also levied on road sections. Accordingly, the possibility of restructuring the traffic flows on the network was strongly limited, since modifying the cost of an edge affected the traffic of many routes simultaneously. If the cost of one or more edges was reduced, the number of travels would increase on all routes containing these edges, based on the function describing the correspondences between part-flows and costs of the routes. However, this change can lead to inconsistency between the appeared transport demands and the number of assigned trips (Equation 4). On the one hand, this inconsistency is not desired in our model, and on the other hand, this phenomenon can be applied to explain the behaviour of the latent demands (e.g. this property of the model can be applied to describe latent demands appearing due to extraordinary low transport costs). 


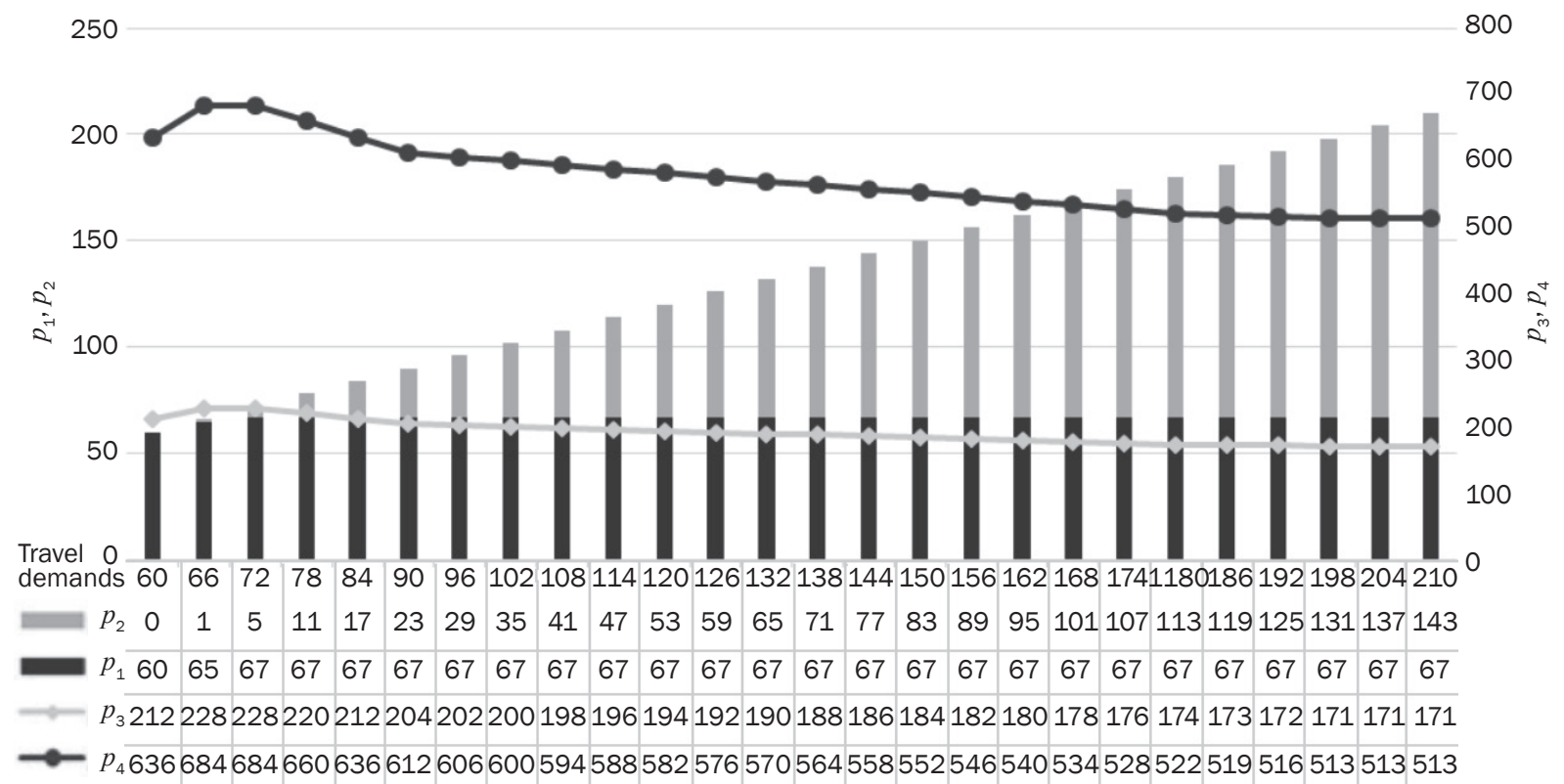

a) Results of Model I

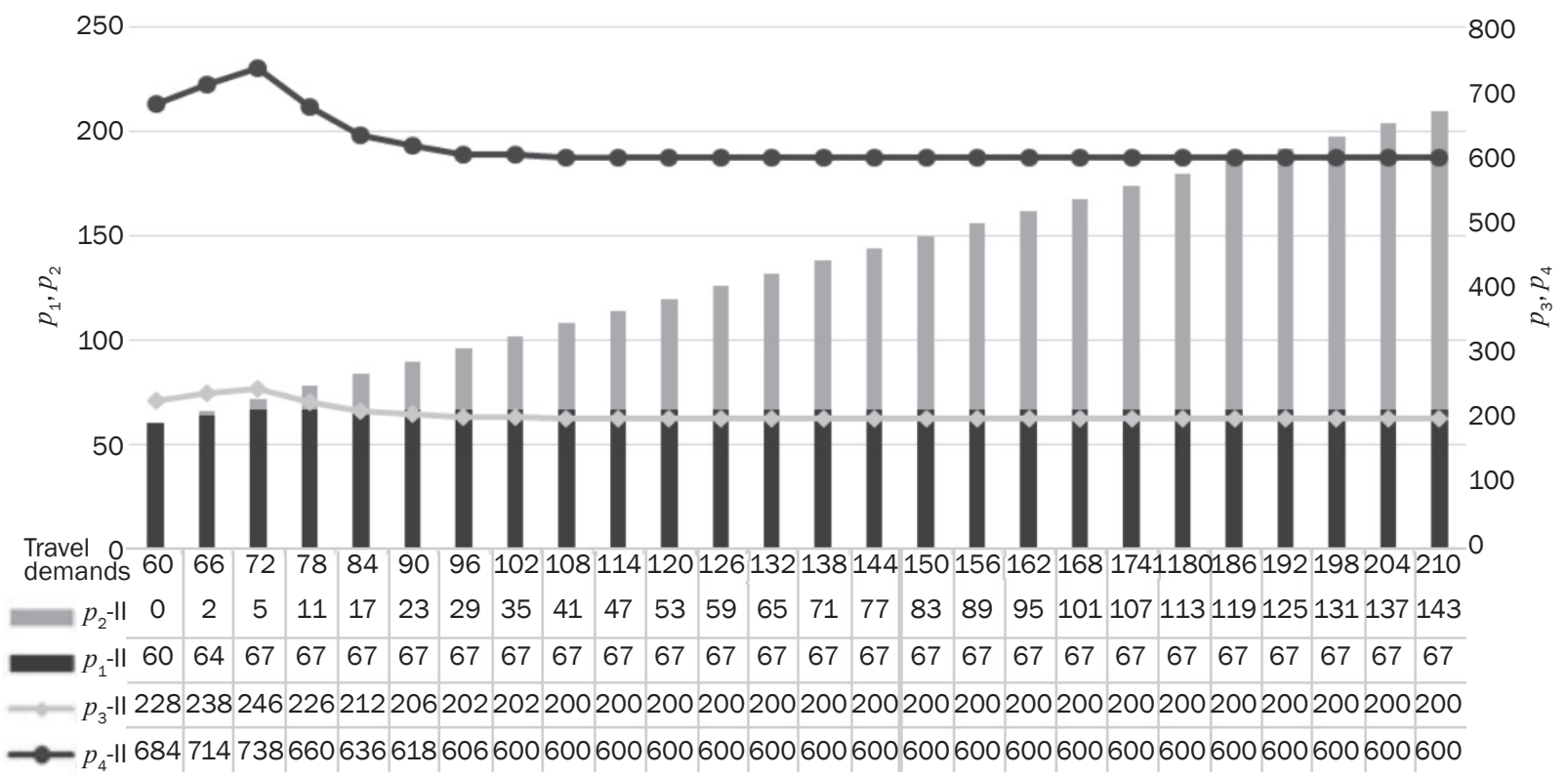

b) Results of Model II

Figure 4 - Parameter values in case of Transport network III

\section{CONCLUSION}

In the paper two types of autonomous transport system managing models have been introduced. The first model solves the demand management and route planning tasks by directly distributing the traffic while minimizing the load of the network. The second model is based on a special cost-based interpretation of the traffic distribution problem.

The considered transport system is assumed to be autonomous to ensure control of the whole mobility process. The travellers can only define the destination and the time of their travel demand.
The introduced two approaches represent different demand management strategies. The aim of the paper was to introduce the developed models and to evaluate the difference between their efficiencies. In the first model, the transport demands have been directly distributed on the network, considering the boundary conditions that have been derived from the volume of transport demands between zones and the pre-defined capacity constraints of the edges. In the second model, the optimization process has been supplemented by the estimation of traffic flows based on the road toll structure. Thus, traffic has not been directly distributed on the network, but based on the road toll 
structure. The aim of the generated optimization problem was to determine the total travel time minimum value as the function of total traffic of the transport system, while realizing most travels.

Based on the elaborated models, the static system optimum of the considered traffic distribution problem has been analysed in case of different transport network types, in light of the change (increase) in transport demands; therefore, the applicability of the mode has been proven. Based on the outcomes of the performed sensitivity analysis, the following parameters have been investigated: total number of realized and postponed travels; total traffic on real edges and the load of the network.

Increments in transport demand increased the number of realized travels to a certain amount until the networks became saturated. From this point, only the number of postponed travels increased proportionally. Nevertheless, total traffic on the edges was still influenced until the point when the networks had been saturated by the shortest possible travels, as the elaborated methods prioritized shorter trips compared to longer ones.

The results proved that in case of these simplified examples the cost-based model has managed to provide equivalent or only slightly less effective results related to parameters $p_{1}$ and $p_{2}$ compared to the directly distributing traffic assignment method. This result is an important milestone in the evolution process of transport system managing framework schemes, since this outcome can prove the applicability of costbased mobility process management models in the field of autonomous transport systems.

Our further research will focus on the development of the second model to approach the reference static system optimum even closer. For example, travel demands can be distinguished based on different criteria. Beside the influence of road toll, it is also planned to apply the developed model to investigate other parameters (e.g. road safety risks of infrastructure elements) that can affect the decisions of road users.

PAUER GÁBOR, Ph.D. hallgató ${ }^{1}$

E-mail: pgabor90@gmail.com

TÖRÖK ÁRPÁD, Ph.D. ${ }^{1}$

E-mail: arpad.torok@auto.bme.hu

${ }^{1}$ Budapesti Múszaki és Gazdaságtudományi Egyetem

Közlekedésmérnöki és Jármúmérnöki Kar

Gépjármútechnológia Tanszék

1111 Budapest, Múegyetem rkp. 3. Magyarország

\section{RENDSZERSZINTŰ OPTIMUM ÉS FELHASZNÁLÓI DÖNTÉS ALAPÚ KÖZLEKEDÉSI MODELLEK ÖSSZEVETÉSE AUTONÓM KÖZLEKEDÉSI RENDSZERBEN}

\author{
ABSZTRAKT \\ Kutatásunk során egy fejlett közlekedésirányitási \\ rendszer igény menedzselési és útvonal tervezési feladatait
}

támogató keretrendszert dolgoztunk ki, autonóm közlekedési rendszert feltételezve.

$A z$ autonóm közlekedési rendszerre vonatkozó optimumok meghatározásához kétféle modellt állitottunk elő. Az elsô modell esetén az optimalizáció változóiként a megvalósult utazások számait kezeltük, míg a második modell esetén a döntési folyamatot az optimalizációs eljárás által definiált útdíjak révén befolyásoltuk. Ezen megközelítések különböző igénykezelési stratégiákat reprezentálnak. Az elsô modell célja a felmerülő közlekedési igények közvetlen hálózatra terhelése, míg a második eljárás a döntést a felhasználókra bízza, ugyanakkor azt jelentôsen befolyásolja az utazások árainak meghatározása révén. Ennek megfelelôen az eloozetes feltételezéseink szerint az elsô modell a hálózat terheltségének optimalizásában hatékonyabb megoldást jelent. Ugyanakkor a második eljárás a felhasználók szemszögébôl, társadalmi oldalról nézve sokkal inkább elfogadható. Fentiek tükrében célunk a kidolgozott modellek bemutatása, és hatékonyságának összevetése volt.

\section{KULCSSZAVAK}

optimalizáció; forgalom szétosztás; útdîj; lineáris programozás; autonóm rendszer;

\section{REFERENCES}

[1] Apronti D, Ksaibati K, Gerow K, Hepner JJ. Estimating traffic volume on Wyoming low volume roads using linear and logistic regression methods. Journal of Traffic and Transportation Engineering (English Edition). 2016;3(6): 493-506. Available from: doi:10.1016/ j.jtte.2016.02.004

[2] Ansari S, Başdere M, Li X, Ouyang Y, Smilowitz K. Advancements in continuous approximation models for logistics and transportation systems: 1996-2016. Transportation Research Part B: Methodological. 2017;107: 229-252. Available from: doi:10.1016/j.trb. 2017.09.019

[3] Kumar P, Rosenberger JM, Iqbal GMD. Mixed integer linear programming approaches for land use planning that limit urban sprawl. Computers \& Industrial Engineering. 2016;102: 33-43. Available from: doi:10.1016/j.cie.2016.10.007

[4] Přibyl O, Svítek M. System-oriented Approach to Smart Cities. In: Proceedings of the $1^{\text {st }}$ IEEE International Smart Cities Conference. IEEE International Smart Cities Conference (ISC2-15), 2015, Guadalajara, Mexico. Available from: doi:10.1109/ISC2.2015.7428760

[5] Hensher DA, Button KJ. (eds.) Handbook of transport modelling. 2nd ed. Emerald Group Publishing Limited; 2007.

[6] Friesz TL, Kim T, Kwon C, Rigdon MA. Approximate network loading and dual-time-scale dynamic user equilibrium. Transportation Research Part B: Methodological. 2011;45(1): 176-207. Available from: doi:10.1016/j.trb.2010.05.003

[7] Nishiyama H, Tada Y, Kato N, Yoshimura N, Toyoshima M, Kadowaki N. Toward Optimized Traffic Distribution for Efficient Network Capacity Utilization in Two-Layered Satellite Networks. IEEE Transactions on Vehicular Technology. 2013;62(3): 1303-1313. Available from: doi:10.1109/TVT.2012.2227861 
[8] Zhang X, Waller ST. Implications of link-based equity objectives on transportation network design problem. Transportation. 2018; 1-31. Available from: doi:10.1007/s11116-018-9888-1

[9] Gonzales EJ, Daganzo CF. Morning commute with competing modes and distributed demand: User equilibrium, system optimum, and pricing. Transportation Research Part B: Methodological. 2012;46(10): 15191534. Available from: doi:10.1016/j.trb.2012.07.009

[10] Li ZC, Lam WH, Wong SC, Sumalee A. Environmentally sustainable toll design for congested road networks with uncertain demand. International Journal of Sustainable Transportation. 2012;6(3):127-155. Available from: doi:10.1080/15568318.2011.570101

[11] Hu TC, Kahng AB. Linear and Integer Programming Made Easy. Springer International Publishing; 2017. Available from: doi:10.1007/978-3-319-24001-5 [Accessed $16^{\text {th }}$ June 2018].

[12] Pauer G, Török Á. Static System Optimum of Linear Traffic Distribution Problem Assuming an Intelligent and Autonomous Transportation System. Periodica Polytechnica Transportation Engineering. 2017;47(1): 64-67. Available from: doi:10.3311/PPtr.11548

[13] Cavone G, Dotoli M, Epicoco N, Seatzu C. A decision making procedure for robust train rescheduling based on mixed integer linear programming and Data Envelopment Analysis. Applied Mathematical Modelling. 2017;52: 255-273. Available from: doi:10.1016/ j.apm.2017.07.030

[14] Pauer G. Defining the Optimization Process of Traffic Distribution Problem with Linear Programming Approach in case of Autonomous Transportation System. In: MOSATT 2017 Modern Safety Technologies in
Transportation: Proceedings of the International Scientific Conference, 2017, Herl'any, Faculty of Aeronautics of Kosice, Slovakia; 2017. p. 124-130. Available from: https://mosatt.lf.tuke.sk/PDF/2017.pdf

[15] Török Á, Pauer G. Optimization of Linear Traffic Distribution Problem in terms of the Road Toll Structure Assuming an Autonomous Transportation System. International Journal for Traffic and Transport Engineering. 2018;8(1): 112-124. Available from: doi:10.7708/ ijtte.2018.8(1).08

[16] Yakimov M. Optimal Models used to Provide Urban Transport Systems Efficiency and Safety. Transportation Research Procedia. 2017;20: 702-708. Available from: doi:10.1016/j.trpro.2017.01.114

[17] Kurczveil T, Becker IU. Optimization of novel charging Infrastructures using linear programming. IFAC-PapersOnLine. 2016;49(3): 227-230. Available from: doi:10.1016/j.ifacol.2016.07.038

[18] Ma W, Qian Z. On the variance of recurrent traffic flow for statistical traffic assignment. Transportation Research Part C: Emerging Technologies. 2017;81: 5782. Available from: doi:10.1016/j.trc.2017.05.009

[19] Ryu S, Chen A, Choi K. Solving the combined modal split and traffic assignment problem with two types of transit impedance function. European Journal of Operational Research. 2017;257(3): 870-880. Available from: doi:10.1016/j.ejor.2016.08.019

[20] Ma J, Li X, Zhou F, Hao W. Designing optimal autonomous vehicle sharing and reservation systems: A linear programming approach. Transportation Research Part C: Emerging Technologies. 2017;84: 124-141. Available from: doi:10.1016/j.trc.2017.08.022 